\title{
Osteosarcoma of breast recurring with mediastinal obstruction
}

\author{
C. W. HUTTON* \\ M.R.C.P.
}

\author{
C. STRANG \\ F.R.C.P.
}

Newcastle General Hospital, Newcastle upon Tyne

\begin{abstract}
Summary
A case of osteogenic sarcoma of the breast in an 82year-old woman is described. It was treated by simple mastectomy but recurred and caused mediastinal obstruction. Radiotherapy gave only mild symptomatic benefit. Previous publications in osteosarcoma of the breast are reviewed.
\end{abstract}

KEY WORDS: radiotherapy

\section{Case report}

An 82-year-old woman presented with a 1-month history of a right breast lump. She had a $3 \mathrm{~cm}$ diameter mass in the upper medial quadrant of the right breast. There was no lymphadenopathy or hepatomegaly.

Chest X-ray and mammography (Fig. 1) showed a $35 \mathrm{~mm}$ diameter radio-dense mass with a radiating ill-defined edge. Bone scan showed marked isotope uptake by the mass. Trucut biopsy showed metaplastic bone with atypical osteoblasts. Except for a mildly elevated plasma alkaline phosphatase, other investigations were normal.

She declined therapy until 5 months later when the mass had become painful and simple mastectomy was performed. Histology showed cellular compact bone with foci of cartilage formation. The periphery of the tumour consisted of pleomorphic sarcoma cells, giant cells and spindle cells producing osteoid. There was scattered stromal breast tissue probably entrapped by tumour. The breast was atrophic with some duct ectasia but no evidence of carcinoma.

Ten months later, she was re-admitted with wheeze, dyspnoea and swelling of the upper limb, neck and face for 1 week due to superior mediastinal obstruction. Her chest X-ray showed a large mediastinal mass (Fig. 2) that took up isotope strongly on bone scan (Fig. 3).

\footnotetext{
*Present address: Department of Medicine, Bristol Royal Infirmary, Bristol.
}

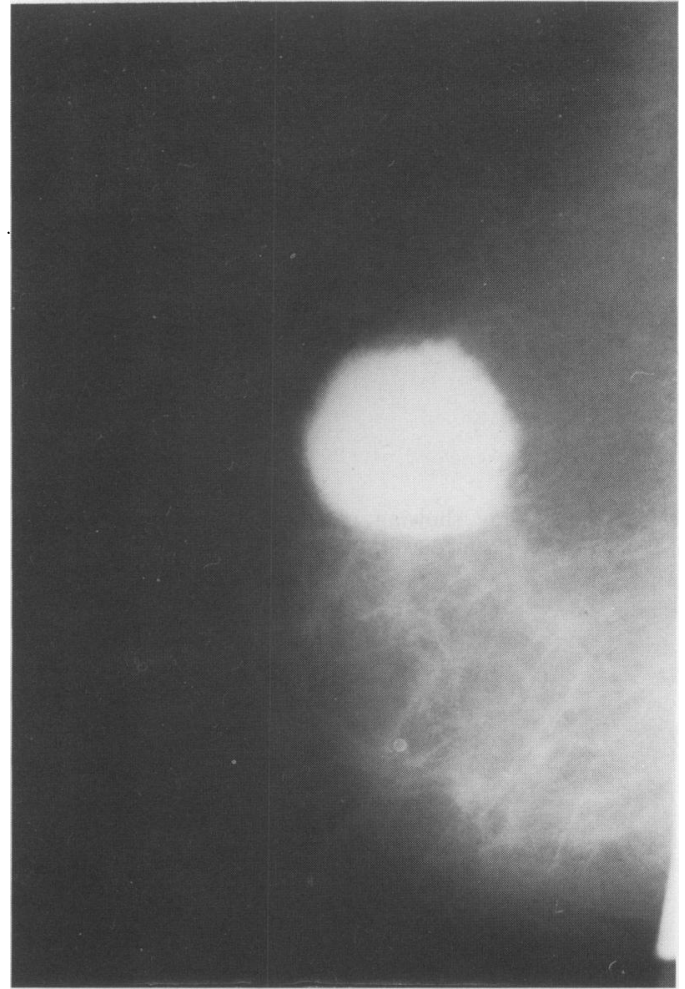

FiG. 1. Mammogram of osteogenic sarcoma at presentation.

She was treated with radiotherapy and steroids which reduced her facial swelling and dyspnoea but she died 1 week after completing her radiotherapy.

\section{Discussion}

Bone containing tumours of the breast have been known since 1700 when one was described by Bonet, and the histology was first described by Lancereaux in 1860 .

Osteosarcoma of the breast is a rare disease, 


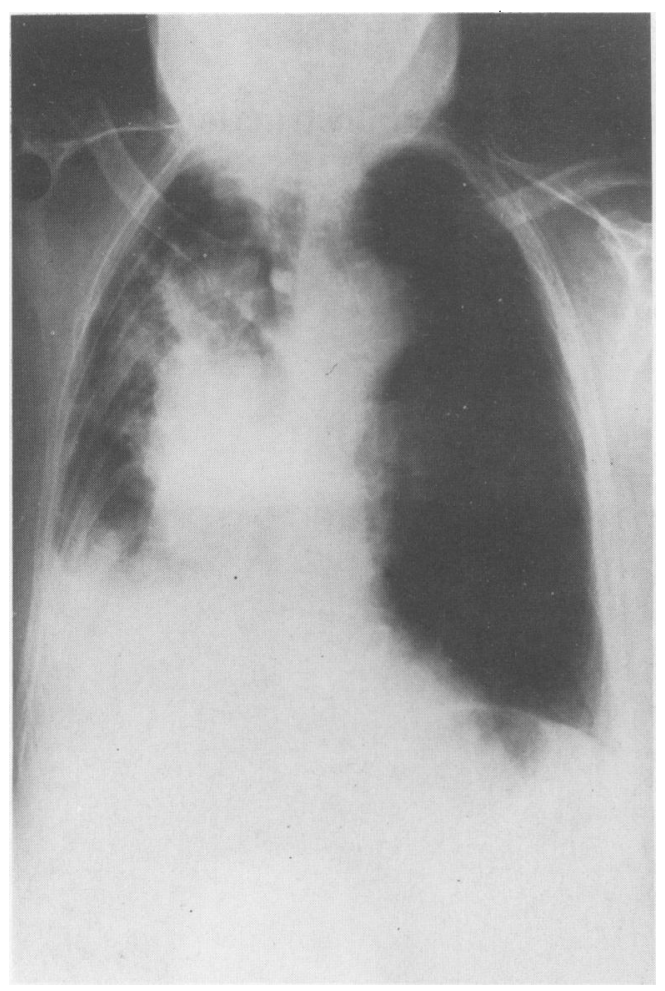

FIG. 2. Chest $\mathrm{X}$-ray showing mediastinal mass presenting with mediastinal obstruction. occurring predominantly in the elderly, though it has been described in a patient aged 14 years (Bruc\& Smith and Taylor, 1969), and once in a male (Sut, 1952). Its rarity is reflected in a review of over 3,000 patients with breast tumours yielding only eight sarcomas, of which only one was an osteosarcoma (Jernstrom, Linberg and Meland, 1963).

The scattered reports are confused by terminolog: Different authorities describe osteoid sarcoma, oste® fibrosarcoma, osteogenic sarcoma and teratoid mixes? tumour. Classifications of the different types of breast tumours containing osteoid, cartilage or bone produce more confusions. The simple grouping of Bruc Smith and Taylor (1969) into adenocarcinoma wi osteoid, cartilage or bone metaplasia; sarcoma with osteoid cartilage or bone metaplasia; cystosarcoma phylloides with bone formation and finally mixes tumours resembling pleomorphic salivary gland tî̀ mours is to be recommended.

Histology gives little help in predicting prognosis A high mitotic index may suggest poor prognosif (Barnes and Pietruszka, 1977; Norris and Taylop, 1967), although this is not consistently supported: (Allan and Soule, 1971). The tumour excised in this case illustrates the pleomorphic histology of osteo genic sarcoma with a mixture of compact bone, foe of cartilage formation and pleomorphic sarcoma cells.

There is no clear understanding of the aetiolog osteogenic sarcoma of the breast. Many authors suggest a relationship to pre-existing fibroadenom

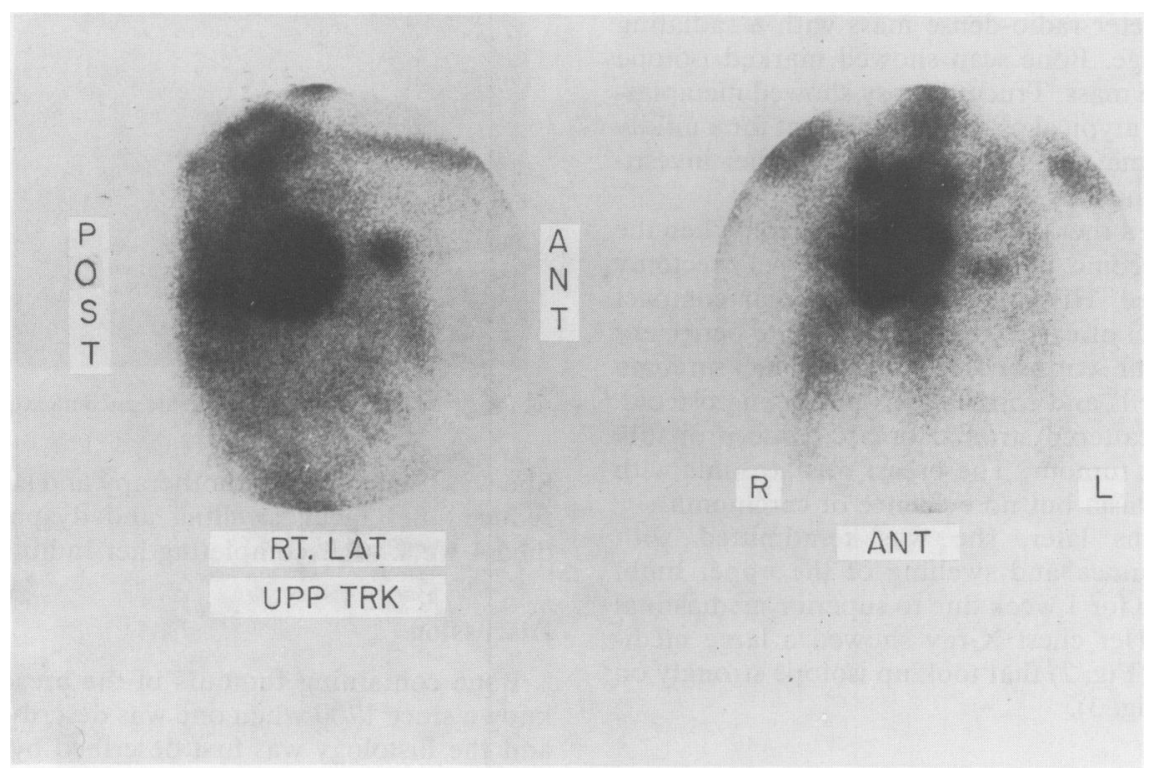

FIG. 3. Isotope bone scan showing uptake in the mediastinal mass shown in Fig. 2. 
(Curran and Dodge, 1962; Jernstrom, 1963; Rottino and Howly, 1945; Stilling, 1881). Ultrastructural studies however, support this hypothesis (GonzalesLicea, Yardley and Hartmann, 1967). Fibroadenomas are not a rare tumour so this may be a chance association.

Other possible mechanism could be misplacement of totipotent cells (McIver, 1923); direct malignant change in stromal cells (Das Gupta, Hajdn and Foote, 1968); or pre-existing breast adenocarcinoma (Oberman, 1965). The natural history of osteosarcoma of the breast remains unclear. Haematogenous and lymphatic spread occur, although the former appears more common and results in early pulmonary metastasis. The usual therapy has been simple mastectomy but its value is uncertain because of the generally poor prognosis and the occasional report of very long survival without treatment (Jernstrom $e t$ al., 1963). In one case, a breast mass was present 40 years before referral (Berg et al., 1962). Beneficial results from chemotherapy have not been reported and radiotherapy is usually disappointing. The complications of the disease are those of the metastases. In this present case, there was spread to the mediastinum, causing mediastinal obstruction. This has not been previously described in osteosarcoma of the breast.

\section{References}

Allan, C.J. \& Soule, E.H. (1971) Osteogenic sarcoma of somatic soft tissues-clinicopathological study of 26 cases and review of the literature. Cancer, 27, 1121.

Barnes, L. \& PiETRuszKa, M. (1977) Sarcomas of the breast-a clinicopathological analysis of ten cases, Cancer, 40, 1577.
Berg, J.W., De Crosse, J.J., Fracchia, A.A. \& Farrow, J.H. (1962) Stromal sarcomas of the breast, a unified approach to connective tissue sarcomas other than cystosarcoma phylloides. Cancer, 15, 418.

BONET, T. (1700) Mammae asseae in virgine cum pectoris hydrope, sepulchretum, sine, anatomia practica, ex cadaveribus morbo denatis. Cramer \& Perachon 1700. Geneva Book 3, Ch. 61, Vol. 2, p. 522.

BRUCE, H., SMiTh, B.H. \& TAYLOR, H.B. (1969) The occurrence of bone and cartilage in mammary tumours. American Journal of Clinical Pathology, 51, 616.

CuRRan, R.C. \& DodGe, O.G. (1962) Sarcoma of breast with particular reference to its origin from fibroadenoma. Journal of Clinical Pathology, 15, 1.

DAS GUPTA, T.K., HAJDN, S.I. \& Foote, F.W. (1968) Extraosseous osteogenic sarcoma. Annals of Surgery, 168, 1011.

GoNZALEZ-LicEA, A., YARDLEY, J.H. \& HARTMANN, W.H. (1967) Malignant tumour of the breast with bone formation. Studies by light and electron microscopy. Cancer, 20, 1231.

JeRnSTROM, P., LinberG, A.L. \& MELAND, O.N. (1963) Osteogenic sarcoma of the mammary gland. American Journal of Clinical Pathology, 40, 521.

LANCEREAUX, E. (1960) Tumeur du sein. Bulletin de la Sociéte d'anatomie de Paris, 35, 292.

LUSSON, L.F. (1958) Reporte de un case de sarcoma osteogenic de la mamma con revision de la literatura. Boletin de la Liga contra el cáncer, 33, 135

MCIVER, M.A. (1923) Teratoid mixed tumours of the breast; report of a case. Annals of Surgery, 77, 354.

NORRIS, H.J. \& TAYLOR, H.B. (1968) Sarcoma and related mesenchymal tumours of the breast. Cancer, 22, 22.

Oberman, H.A. (1965) Sarcomas of the breast. Cancer, 18, 1233.

RotTino, A. \& Howly, C.P. (1945) Osteoid sarcoma of the breast; a complication of fibroadenoma. Archives of Pathology, 40, 44.

StILling, H. (1881) Ueber osteoid sarkome der Weiblichen Brustdrusse. Deutsche Zeitschrift fur Chirurgie, 15, 247.

SUN, P.Y. (1952) Osteogenic sarcoma of the breast-review of the literature and a case report. Chinese Medical Journal, 70, 46.

(Accepted 16 March 1983) 